\title{
Technical Efficiency of Soya Beans Production in Mubi North Local Government Area of Adamawa State, Nigeria Joyce D Moses
}

Department of Agricultural Economics and extension, Faculty of Agricultural sciences. Adamawa State University Mubi. Adamawa State, Nigeria

\begin{abstract}
The study was conducted to evaluate the technical efficiency of soya bean production in Mubi North Local Government Area of Adamawa State, Nigeria. The objective of the study was to examine the inputs and output relationship of soya bean production in the study area. A multi stage random sampling techniques was used to select 80 respondents in the study area who were noted for soya beans production. Primary data were collected from the respondents with the aid of structured questionnaire and were analyzed using stochastic frontier function. It was therefore recommended that inputs such as seeds, fertilizers and agrochemicals which were the major inputs that increase the output of soya bean production in the study area should be made available on time, in right amounts and at affordable prices to the farmer's stakeholders in agriculture. Proper orientation and knowledge should be given to people willing to go into the cultivation of soya beans on the appropriate time of planting. Extension services should also be rendered effectively.
\end{abstract}

Keywords - Soya Beans production, Adamawa state, Nigeria, Mubi north, Nigeria.

\section{INTRODUCTION}

The agricultural sector in Nigeria has suffered many reversals during the past couple of decades. From era of booming of export trade in agricultural commodities, the Nigerian agricultural sector has degenerated to an import dependent one (Ojo and Ehinmowo, 2010). Subsequently, it has failed to generate significant foreign exchange, feed agro-allied industries, improve the living standards of farming households and rural dwellers and provide effective demand for industrial goods and services. Increasing food production however is vital for enhancing future food security in the country as this is no longer debatable but a necessity. To achieve this, good knowledge of the current efficiency or inefficiency inherent in the crop production sub-sector as well as factors responsible for the level of efficiency and inefficiency must be critically examined.

Soya bean is the richest source of plant protein known to man (Odusanya, 2002). It is also an important source of income. It can contribute to the enhanced sustainability of intensified cropping system by improving soil fertility through nitrogen fixation, permitting a longer duration of ground cover in the cropping sequence and providing useful crop residues for animal feed. Nigeria is still ranked amongst the lowest soya beans producing countries in the world (Faostat, 2009). This can be attributed to poor and inefficient usage of resources by farmers. Resource use efficiency study is very important for increased output and profitability of farmers. It is widely held that efficiency is at the heart of agricultural production. This is because the scope of agricultural production can be expanded and sustained by farmers through efficient use of resources (Udoh, 2000). For these reasons, efficiency has remained an important subject of empirical investigation particularly in developing economies where majority of the farmers are resource-poor. These problems identified have given rise to the following research questions.

\section{METHODOLOGY}

\subsection{Description of the Study Area}

This study was conducted in Mubi north local government area of Adamawa state. Mubi North local government of Adamawa state lies on the west bank of the Yedseram River, a stream that flows into Lake Chad and is situated on the western flanks of the Mandara Mountain. It shares common boundaries with Borno State to the North Hong Local Government Area to the West, Maiha Local Government to the South and Cameroun Republic to the East.

Temperature is normally warm to hot with minimum temperature of 120c and maximum temperature of 370c (Adebayo, 2004). The ethnic groups are mainly Fali, Gude, Marghi and Fulani. The inhabitants are predominantly farmers and traders.

Mubi is the capital of Mubi North Local Government Area of Adamawa State in Nigeria. It lies on latitude $10^{\circ} 32 \mathrm{~N}$ to $10^{\circ} 11$ $\mathrm{N}$ and longitude $13^{\circ} 12 \mathrm{E}$ to $13^{\circ} 35^{\prime} \mathrm{E}$, with a total land mass of $506.4 \mathrm{Km} 2$ and a population size of 759,045 people. Mubi has a tropical climate which is determined by the movement of the Inter Tropical Convergence Zone (ITCZ), as well as the effect 
of relief (Ray, 2007). Rainfall begins in April, progressing and reaching its peak in July/August and stops most of the time in October. Average annual rainfall ranges between $998 \mathrm{~mm}$ and $1262 \mathrm{~mm}$. The areas just below the Mandara Mountains record the highest rains. Rainfall intensity is high with rainy days making up to $87 \%$ of the days with more than $20 \mathrm{~mm}$ of rainfall (Ray, 2007). Alongside air and water, soil is another vital resource that provides the basis for human living (Adebayo, 2004). The soil is composed of weathered rock materials (parent material), organic matter, moisture content, and dissolved minerals in the air (Adebayo, 2004). Thus, it forms a very important medium for plant growth. However, soils vary in their texture, structure, colour, mineral content and moisture holding capacity (Adebayo, 2004). Some of these physical properties collectively form the basis for their classification.

The soil of Mubi regions therefore, fall under the category of ferruginous tropical soils of Nigeria based on the genetic classification made by the Food and Agricultural Organization of the United Nations (Adebayo, 2004).

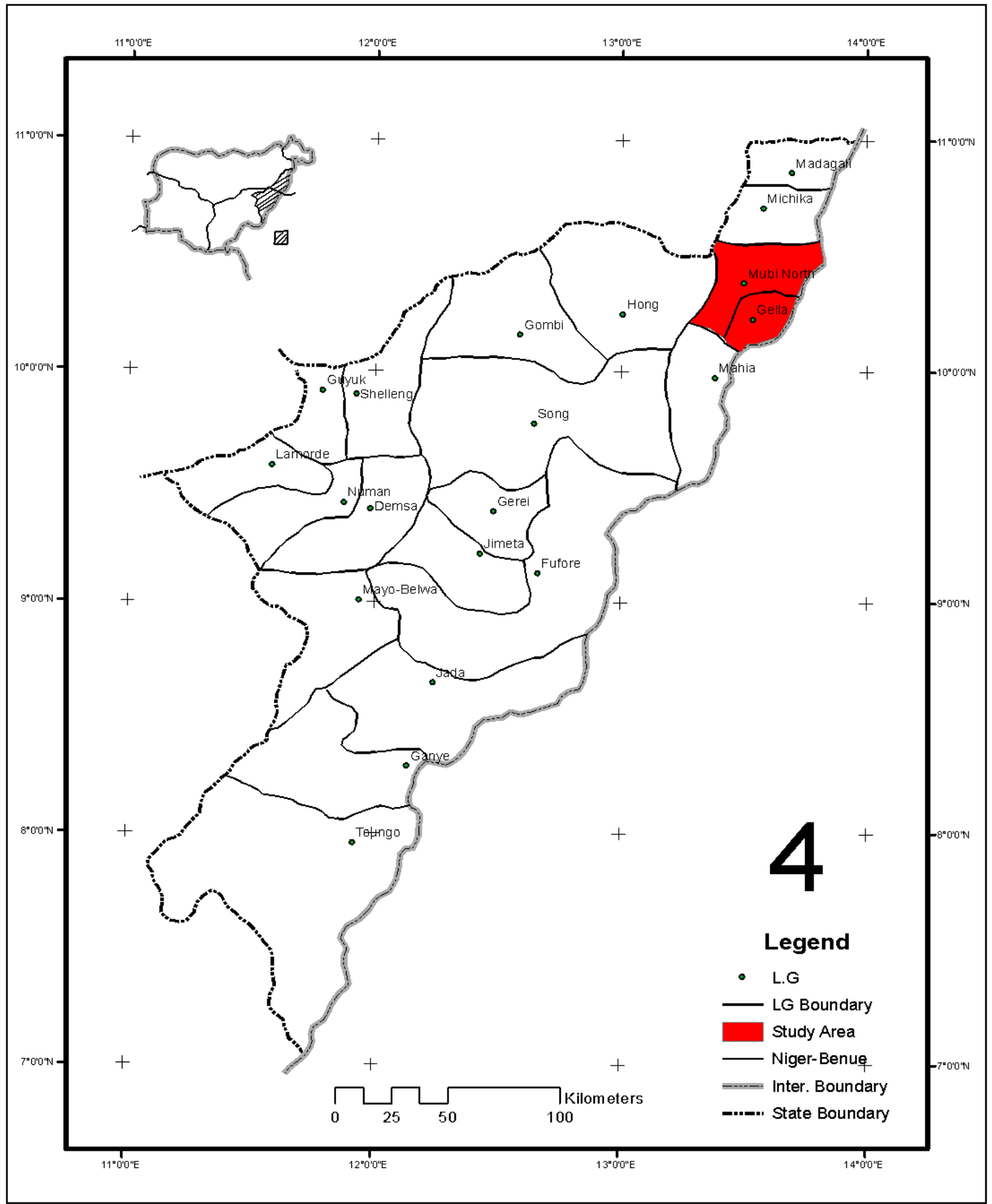

Figure 1: MAP OF AdAMAWA STATE, SHOWING A PORTION OF MUBi NORTH LOCAL GoverNMENT 


\subsection{Sources of Data and Sampling procedure}

Data for this research was collected from primary sources, using structured questionnaires. The questions were being structured to elicit answers on the objectives of study.

Based on the study, the population targeted was soya bean farmers in the study area (Mubi north, LGA) of Adamawa State. Mubi north comprises of four (4) districts (Mubi-Town, Bahuli, Mayo-Bani and Muchalla) out of which it is divided into eleven (11) political wards namely; Mijilu, Lokuwa, Mayo-Bani, Kolere, Digil, Yelwa, Vimtim, Muchalla, Bahulli, Sabonlayi and betso. The multi-stage random sampling techniques was used in selecting the respondents, out of the population, four wards werechosen from the local Government area that were noted for soyabean production from which 20 farmers were selected from each ward to make a total number of 80 respondents.

\subsection{Analytical Techniques}

The analytical tool that was used in achieving the objective of the study was Stochastic Frontier Function Cobb-Douglas production frontier function was estimated using the Maximum Likelihood Techniques. These two frontiers are the basis for deriving farm level efficiency measures. The stochastic production frontier was written as:

$$
\operatorname{Ln} Y_{i}=\ln \beta_{0}+\sum_{i}^{s}={ }_{1} \beta_{j} \ln X_{i j}+v i-\mu_{i}
$$

Where:

$\ln =$ the natural logarithm

$\mathrm{Yi}=$ Farm output $(\mathrm{kg})$

$\mathrm{Xij}=$ Vector of farm inputs $(\mathrm{X} 1-\mathrm{X} 5)$ used

$\mathrm{X} 1=$ Farm Size (hectare)

$\mathrm{X} 2=$ Quantity of seeds $(\mathrm{kg})$

$\mathrm{X} 3$ = Fertilizer $(\mathrm{kg})$

$\mathrm{X} 4=$ Total Labour used (man hours) and

X5 = Volume of Agrochemicals (litre)

$\mathrm{v}=$ random variability in the production that cannot be influenced by the farmer;

$\mu=$ deviation from maximum potential output attributable to technical inefficiency.

$\beta o=$ intercept;

$\beta \mathrm{i}=$ vector of production function parameters to be estimated;

$\mathrm{i}=1,2,3, \mathrm{n}$ farms;

$\mathrm{j}=1,2,3$, $\mathrm{m}$ inputs.

The inefficiency model it is specified as:

$$
u i=\delta 0+\delta 1 Z 1+\delta 2 Z 2+\delta 3 Z 3+\delta 4 Z 4+\delta 5 Z 5+\delta 6 Z 6
$$

Where,

$u i=$ technical inefficiency effect of the ith farm;

$\mathrm{Z} 1$ = educational level of farmer in years of formal education completed;

$\mathrm{Z} 2$ = household size (no.);

$\mathrm{Z3}=$ age of farmer in years;

$\mathrm{Z} 4$ = farming experience in years 
$\mathrm{Z5}=$ membership of cooperative society

$\delta 0=$ constant

$\delta 1-\delta 6=$ parameters to be estimated.

The $\beta$ and $\delta$ coefficients are un-known parameters to be estimated along with the variance parameters $\delta 2$ and $\gamma$. Aigner et al. (1977), Jondrow et al. (1982), and Green (1993) defined $\delta 2$ and $\lambda$ as:

$$
\delta 2=\delta 2 \mathrm{v}+\delta 2 \mathrm{u} \text { and } \lambda=\delta \mathrm{u} / \delta \mathrm{v}
$$

Battese and Corra (1977) defined $\gamma$ as total variation of actual output towards its frontier such that $\gamma=\delta 2 \mathrm{u} / \delta 2$

Consequently, $0<\gamma<1$ and one may obtain the estimated value of $\gamma$

The $\delta 2$, and $\gamma$, coefficients are the diagnostic statistics that indicate the relevance of the use of the stochastic production frontier function and the correctness of the assumptions made on the distribution form of the error term. The $\delta 2$ indicates the goodness of fit and the correctness of the distributional form assumed for the composite error term. The $\gamma$, indicates that the systematic influences that are unexplained by the production function are the dominant sources of random errors.

\section{RESULTS AND DISCUSSION}

\subsection{Stochastic Frontier Production Function and Inefficiency Model Result}

From table below the results of farm size revealed that the estimated coefficient was 0.933 . This positive effect of farm size on soya bean output implies that a 1 percent increase in the size of farm holding will lead to an increase in output of soya bean by $9.33 \mathrm{~kg}$. This could be so because large farm size motivates adoption of innovations which can translate into higher output. The coefficient of farm size was statistically significant at 1 percent level of probability, indicating the relevance of farm size on soya bean production in the study area. This result is in line with the work of Moses (2015), that farm size contributes output.

The coefficient of seed used positively affects output with a value of 0.517 . The implication of this positive effect is that if quantity of seed used increases by 5 percent, output will rise by $5.17 \mathrm{~kg}$. Production of soya bean cannot be embarked upon if seed is not involved in the production process; hence, quantity of seed used was significant in soya bean production at 5 percent probability level. This result is in agreement with Moses (2015) and Tashikalma (2011).

The estimated coefficient fertilizer was 0.239 of the variable was positive. This agrees with the a priori expectation that as the quantity of fertilizer used increases, yield increases as well. However, fertilizer use was not significant because Soya bean does not require much fertilizer. Also, Soya bean improves soil fertility by converting and fixing nitrogen from the atmosphere into the soil.

The estimated coefficient of labour was 0.325 . The positive effect implies that 5 percent increase in family labour will leads to increase in output of soya beans with $3.25 \mathrm{~kg}$. And it was significant at 5 percent difference from zero since family labour reduces hired labour cost in the production of soya beans in the study area. A similar result by Amaza et al (2006) and Moses (2015) equally reported that labour is an important variable in agricultural production.

The coefficient for volume of agrochemicals was negatively signed -0.919 and is not significant for the production of soya bean by the respondents. The implication of the result is that as the volume of agrochemicals used for the production of soya bean increases by a litre, the quantity of soya bean produced decreases. The sign was not as expected because use of agrochemicals reduces drudgery in farm operations such as weeding and clearing as well as increase quantity of output produced stemming from control of pests and diseases.

The estimated gamma parameter $(\gamma)$ is 0.991 for soya beans and also statistically significant at 1 percent level, indicating that 99 percent of the variation in the total output of production among the sampled farmers is due to differences in their technical efficiencies in the study area. The estimated sigma square $\left(\delta^{2}\right)$ for the respondents were $(0.308)$ and significantly different from zero at 1 percent level, this indicates a good fit and the correctness of the specified distributional assumption of the composite error term. 


\section{TABLE 1}

\section{MAXIMUM LIKELIHOOD ESTIMATES OF THE STOCHASTIC FRONTIER PRODUCTION FUNCTION FOR SOYA} BEANS FARMERS

\begin{tabular}{|lllll|}
\hline Variable Input & Parameter & Coefficient & standard Error & T- ratio \\
\hline Constant & $\left(\mathrm{B}_{0}\right)$ & 0.104 & 0.106 & 0.986 \\
\hline Farm size & $\left(\mathrm{B}_{1}\right)$ & $0.933^{* * *}$ & 0.759 & 0.122 \\
\hline Quantity of seed & $\left(\mathrm{B}_{2}\right)$ & $0.517^{* *}$ & 0.322 & 0.160 \\
\hline Fertilizer & $\left(\mathrm{B}_{3}\right)$ & 0.239 & 0.499 & 0.479 \\
\hline Total Labour & $\left(\mathrm{B}_{4}\right)$ & $0.325^{* *}$ & 0.337 & 0.963 \\
\hline Volume of Agrochemical & $\left(\mathrm{B}_{5}\right)$ & -0.919 & 0.307 & -0.298 \\
\hline Inefficiency model & & & 0.844 & -0.576 \\
\hline Constant & $(\delta 0)$ & -0.486 & 0.814 & -0.937 \\
\hline Educational level & $\left(\delta_{1}\right)$ & $-0.763^{* *}$ & 0.305 & -0.106 \\
\hline Household size & $\left(\delta_{2}\right)$ & 0.325 & 0.113 & -0.101 \\
\hline Age & $\left(\delta_{3}\right)$ & $-0.117^{* * *}$ & 0.261 & 0.610 \\
\hline Farming experience & $\left(\delta_{4}\right)$ & $-0.265^{* * *}$ & 0.459 & 0.105 \\
\hline Membership of Cooperative $\left(\delta_{5}\right)$ & $0.280^{* * *}$ & 0.293 \\
\hline Variances & & & 0.969 & 0.102 \\
\hline Sigma-squared & $(\sigma 2)$ & 0.308 & 2016 & \\
\hline Gamma & $(\gamma)$ & 0.991 & & \\
\hline
\end{tabular}

\footnotetext{
Source: computer printout. 2016

***Estimates are significant at $1 \%$ level,

** Estimates are significant at 5\% level.

*Estimates are significant at $10 \%$ level.
}

\subsection{Determination of Technical Inefficiency of the Respondents}

It should be noted that the negative signs in the inefficiency of the respondents implies positive outcome while the positive sign implies that the outcome is negative vice versa. The negatively estimated coefficient for education is -0.763 for soya bean production this implies that respondents with greater years of schooling tend to be more efficient, because as schooling years increases, technical inefficiency tend to reduce. Technical inefficiency tends to increase output of soya beans by $7.63 \mathrm{~kg}$ by 10 percent increase. It could be plausible to say that respondents with considerable years of education respond readily to effective decision making in agriculture. This finding is supported by findings obtained by Battese and Coelli (1995) in their study on model for technical inefficiency effect, in stochastic frontier production function for Panel Data. Educational level was statistically significant at 10 percent probability level. Roger and Shoemaker (1971) and Obibuaku (1983) stated that education is not only an important determinant of adoption of innovations but also a tool for successful implementation of innovation.

Household size coefficient had a positive sign in the model which is 0.325 . An increase in the number of people in a household will lead to a decline in technical inefficiency of the farmers. Therefore, respondents with larger household sizes tend to have less technically efficient than households with big number of people unless they are all productive.

This is in agreement with the findings of Ekwe and Nwachukwu (2006) who reported that the average household size in Africa was 8-9 persons per household. This is highly indicative of the extended family system in the study area where parents and other relations dwell together as a household. Implication of this finding is that large family size of the farmers probably 
necessitated them to learn new agricultural technologies for augmenting production and increasing returns. More family labour would also be readily available since relatively large household size is an obvious advantage in terms of labour supply.

Coefficient of age has negative effect -0.117 on the respondents' technical inefficiency implying that it has positive effect on technical efficiency. This suggests that the older the respondents, the lower the technical inefficiency. As the respondents' age increases by 1 percent the technical inefficiency decreases by 1.17 percent. This is significant from zero at 1 percent. The positive effect of age on technical efficiency indicates that the agility and energetic capability of the respondents contribute to the production of soya beans. This is in agreement with the findings of Shelma (2014), who in his findings reported the positive effect of age on technical efficiency

Farming experience of the respondents had negative and significant coefficient of -0.265 , implying that respondents with higher farming experience tend to be more technically efficient in the production of soya bean. A rise in farming experience of the respondents could enhance the skill of the farmers which in turn increase their efficiency. Farming experience was significant at 1 percent level of probability indicating the relevance of accumulation of experience in a farming activity. Maurice (2004) also reported that farming experience increases efficiency in farmers.

Membership of cooperative society was found to have positive effect on technical inefficiency of respondents indicating a rise in technical efficiency as years of cooperative society membership will still not increase their output since they were mostly using their personal savings and vice versa. However, it was statistically significant at 1 percent level as majority of the respondents were not members of any cooperative group. Cooperative society serves as a medium for information exchange that can improve farm output of respondents. This finding contract with the findings of Shelma (2014), who in his findings reported that the longer a respondent stayed in a cooperative society, the lower is his allocative inefficiency.

\subsection{Technical Efficiency of soya beans farmers in the study area.}

The general distribution of respondents' efficiency presented in Table below shows a minimum of 72 percent and a maximum of 99 percent with a mean efficiency of 90 percent. The obtained mean technical efficiency of the respondents indicates that soya bean farmers in the study area have 10 percent chance for improving production efficiency using the existing technology of the best farmer. Therefore, there is need to increase production by utilizing available resources to attain the frontier level. About 10 percent of the respondents fall between technical efficiency of 70 - 80 . Respondents operating at technical efficiency of between 81-90 were 15 percent while respondents with technical efficiency above 91 above were 75 percent. This revealed that there is room for improvement.

TABLE 2

THE TECHNICAL EFFICIENCY DISTRIBUTION OF SOYA BEANS FARMERS.

\begin{tabular}{|c|c|c|}
\hline Variable & Soya beans farming & \\
\hline Family size & No. of farmer's & Percentages \\
\hline $70-80$ & 8 & 10 \\
\hline $81-90$ & 12 & 15 \\
\hline $91-100$ & 60 & 75 \\
\hline Mean & $\mathbf{0 . 9}$ & $\mathbf{1 0 0}$ \\
\hline
\end{tabular}

Source: field survey 2016

\section{CONCLUSION}

If the efficiency level of the most efficient farmer is to be attained by all the farmers, cost savings can be achieved with the present level of technology and prices of inputs.

\section{REFERENCES}

[1] Adebayo, A.A (2004) Mubi Regions. A Geographical synthesis.Pracklet publishers. Yola - Nigeria 32 - 38pp

[2] Adebayo, E.F. and J.I. Onu (1999).Economics of Rice Production in Yola North and South Local Government areas of Adamawa State, Nigeria. Nigerian Journal of Tropical Agriculture, Federal University of Technology, Yola 115-120

[3] Amaze, P.S, Onu, J.I and Okunmadewa, F.Y. (2006). Identification of factors that influence the Technical Efficiency of cotton farmers in Nigeria. Nigeria Agricultural Development studies 2(1): 133 - 145 
[4] Battese, G.E and Coelli, T.J. (1995). -A Model for Technical Inefficiency Effects in a Stochastic Frontier Production Function for Panel Data.ll Empirical Economics 20:325-332.

[5] FAO, 2006.FAOSTAT. Food and Agriculture Organization of the United Nations

[6] FAO, 2010.FAOSTAT. Food and Agriculture Organization of the United Nations

[7] FAOSTATS (2009). Food and Agriculture Statistical Database Internet:

[8] Federal Office of Statistics/ Federal Bureau of Statistics (1999).Poverty and Agricultural Sector in Nigeria, Poverty Incidence of Farmers by Region pp 22-23, Federal Office of Statistics/ Federal Bureau of Statistics.

[9] http://apps.fao.org/page/collections?Subset=agriculture.

[10] http://www.faostat2009.org.

[11] Maurice, D. C (2004).Resource production in cereal crop production among Fadama farmers of Adamawa state Nigeria. Unpublished master's thesis, university of Maiduguri

[12] Moses, J. D (2015).Analysis of technical efficiency of rainfed rice farmers in North Eastern Nigeria, Adamawa State.University Journal of Agricultureal science. 3(2): 7 -14

[13] Moses. J.D, Daniel. A. Dwana, Dr. Giroh.D.Y, Zalkuwi. J, Akindele.O (2015). The Influence of Socio-Economic Characteristics on Consumers' Preference on Fish Purchase In Yola North Local Government Area, Adamawa State Preparation of Papers for International Journal of Environment \& Agriculture Research.

[14] Obibuaku, L.O. (1983). The Nigeria Extension Service: “An Assessment”. A Commissioned National Research Report.Department of Agricultural \& Rural Development, N.I.S.E.R Ibadan, 1983.PP. 89.

[15] Ojo, S.O., and Ehinmowo, O.O. (2010).Economic Analysis of Kola-nut Production in Nigeria.Journal of Social Science, 22 (1): 1-5.

[16] Okuneye, P.A. (2002): FAO Production Year Book Vol. 45, Rome.

[17] Olayide, S.O., and Heady, E.O. (1982). Introduction to Agricultural Production Economics. University of Ibadan Press, Ibadan, Nigeria

[18] Olukosi, J.O and Ogungbile, A.O. (1989). Introduction to Production Economics: Principles and Application. Agitab Publisher Limited, Zaria, Nigeria, pp. 20-30.

[19] Ray, H.H. (2007), "The effects of physical techniques on soil conservation in Mubi and environs, Adamawa State, Nigeria", Journal of Sustainable Development in Agriculture and Environment, Vol. 3 pp. 112-121.

[20] Rogers, E.M. and Shoemaker, P.C. (1971).Diffusion Innovations. The free Press of Glencoe, N.Y. PP. 367.

[21] Shalma, H. J,. (2014). Economic analysis of soya bean production under sasakawa global 2000 project in kaduna state, Nigeria. Ahmadu bello university, zaria, nigeria. March 2014

[22] Tashikalma, A. K. (2011). Comparative Economic Analysis of some Rainfed and irrigated food crops in Adamawa state, Nigeria. Unpublished Doctoral Thesis, Abubakar Balewa University, Bauchi.

[23] Udoh, E.J. (2000). —Land Management Resource. Use Efficiency Among Farmers in South Eastern Nigeriall Un-published Ph.D thesis, Department of Agricultural Economics, University of Ibadan.

[24] Udoh, E.J. and Akintola, J.O. (2001). Land Management and Resource Use Efficiency Among Farmers in South-Eastern Nigeria, p. 46. Elshada Global Ventures, Ibadan.

[25] www.world meters.info/world-population

[26] Zalkuwi, J.,Yusuf, C., and Ibrahim, A., (2014). Analysis of Cost and Return in Cowpea Production: A Case Study Guyuk Local Government Area of Adamawa State, Nigeria. The International Journal Of Humanities \& Social Studies (ISSN 2321 - 9203) www.theijhss.com

[27] Zalkuwi, J., Ibrahim, A., and Kwakanapwa, E., (2014). Analysis of Cost and Return of Maize Production inNuman Local Government Area of Adamawa State, Nigeria, international journal of innovation research and development, ISSN 2278 - 0211 (Online, )Vol 3 Issue 4, April, 2014.

[28] Zalkuwi. J, Udhav P.S, Amita M and Asabe 2015. Cost and Return Analysis of Local Chicken Marketing in Mubi North Local Government Area of Adamawa State, Nigeria. 